\title{
COVID-19: FORECAST OF AN EMERGING URGENCY IN PAKISTAN
}

\author{
Rabia Chaudhry ${ }^{1}$, Asif hanif ${ }^{1}$, Muhammad Chaudhary ${ }^{2}$, Sadia Minhas ${ }^{3}$, Khalid Mirza ${ }^{3}$, \\ Tahira Ashraf ${ }^{1}$, and Syed Gilani ${ }^{1}$ \\ ${ }^{1}$ The University of Lahore \\ ${ }^{2}$ University of Derby \\ ${ }^{3}$ Akhtar Saeed Medical and Dental College
}

April 28, 2020

\begin{abstract}
Coronavirus disease 2019 (COVID-19) has been declared a pandemic of 2020 by World Health Organization (WHO). Due to its novelty there is very little knowledge available about it, and thus there is a great need of collection of data related to COVID-19, from all around the world. Hence, we have conducted this study, collecting daily data on COVID-19 from National Institute of Health (NIH) Pakistan and WHO, to map the epidemiology of COVID-19 outbreak, forecast its trajectory from 4th April till 30th April, and review the preventive measures taken by government of Pakistan. The data was collected from NIH-Pakistan and WHO official released reports, analysis was done using SPSS version 23 and forecasting was made using time series modeler / expert modeler. The purpose of this study is to draw the attention of international as well as national governing bodies towards the rapidly rising number of COVID-19 cases in Pakistan, and the urgency to evaluate the efficacy of currently implemented strategy against COVID-19. According to this study, the spread of COVID-19 is slower than predicted, but there is an alarming increase in growth rate now, and the predicted COVID-19 cases by the end of April can go up to around 8,000 or higher. Hence, it is crucial for the governing bodies to re-evaluate the current situation and implemented strategy. Discussions should be conducted by the administrators and researchers for any change in the strategy if required, before the situation further aggravates.
\end{abstract}

COVID-19: FORECAST OF AN EMERGING URGENCY IN PAKISTAN COVID-19 FORECAST, EPIDEMIOLOGY, AND PREVENTION

AUTHORS Rabia Mushtaq Chaudhry ${ }^{1,2^{*}}$ rabia-mushtaq@live.comAsif Hanif ${ }^{3}$ asif.hanif@ahs.uol.edu.pk , mebiostatistician@gmail.comMuhammad AbdulBasit Chaudhary ${ }^{4}$ mabasit.ft@gmail.comSadia Minhas ${ }^{5,6}$ sadiawasif81@gmail. Saeed Mirza 7

khalidsaeed196300@gmail.comTahira Ashraf ${ }^{8}$ tahira.ashraf@rsmi.uol.edu.pkSyed Amir Gilani ${ }^{9}$ profgilani@gmail.com

${ }^{1}$ M-Phil Public Health Scholar, University Institute of Public Health, University of Lahore, Lahore, Pakistan.

${ }^{2}$ Demonstrator Oral Medicine, Akhtar Saeed Medical and Dental College, Lahore, Pakistan.

${ }^{3}$ Associate Professor, University Institute of Public Health, University of Lahore, Lahore, Pakistan

4 Masters Public and Environmental Health Scholar, University of Derby, United Kingdom

5. Assistant Professor, Oral Pathology, Akhtar Saeed Medical and Dental College, Lahore, Pakistan

6. PhD Scholar Microbiology and Virology, University of Lahore, Lahore, Pakistan 
7. Assistant Professor, Periodontology, Akhtar Saeed medical and Dental College, Lahore, Pakistan

8. S. Lecturer: University Institute of Radiological Sciences \& Medical Imaging Technology, The university of Lahore

9. Professor: University Institute of Radiological Sciences \& Medical Imaging Technology, The university of Lahore

CORRESPONDING AUTHOR:NAME: Rabia Mushtaq Chaudhry:ASSOCIATION: M-Phil Public Health Scholar, University Institute of Public Health, University of Lahore, Lahore, Pakistan / Demonstrator Oral Medicine, Akhtar Saeed Medical and Dental College, Lahore, Pakistan.EMAIL ADDRESS : rabia-mushtaq@live.com TELEPHONE: +923366332345

SUMMARY: Coronavirus disease 2019 (COVID-19) has been declared a pandemic of 2020 by World Health Organization (WHO). Due to its novelty there is very little knowledge available about it, and thus there is a great need of collection of data related to COVID-19, from all around the world. Hence, we have conducted this study, collecting daily data on COVID-19 from National Institute of Health (NIH) Pakistan and WHO, to map the epidemiology of COVID-19 outbreak, forecast its trajectory from $4^{\text {th }}$ April till $30^{\text {th }}$ April, and review the preventive measures taken by government of Pakistan. The data was collected from NIH-Pakistan and WHO official released reports, analysis was done using SPSS version 23, and forecasting was made using time series modeler / expert modeler. The purpose of this study is to draw the attention of international as well as national governing bodies towards the rapidly rising number of COVID-19 cases in Pakistan, and the urgency to evaluate the efficacy of currently implemented strategy against COVID-19. According to this study, the spread of COVID-19 is slower than predicted, but there is an alarming increase in growth rate now, and the predicted COVID-19 cases by the end of April can go up to around 8,000 or higher. Hence, it is crucial for the governing bodies to re-evaluate the current situation and implemented strategy. Discussions should be conducted by the administrators and researchers for any change in the strategy if required, before the situation further aggravates.

KEYWORDS: COVID-19 virus; Epidemiology; COVID-19 Forecasting; COVID-19 in Pakistan.

\section{ABBREVIATIONS:}

- COVID-19: Corona virus Disease- 2019

- CPEC: China Pakistan Economic Corridor

- WHO: World Health Organization

- NIH-Pakistan: National Institute of Health - Pakistan

INTRODUCTION: Currently, what has now been declared as a pandemic, a severe acute respiratory syndrome coronavirus 2 (SARS-CoV-2), was first reported in a livestock market in Wuhan, Hubei province of China, on December 12'2019 (Huang et al., 2020; Li et al, 2020). The first case of this pandemic was presented with pneumonia of unexplained cause, and by December 29 '2019 there were 27 cases that presented with similar signs and symptoms, out of which seven were in a critical situation. After ruling out influenza and other possible coronaviruses, it was declared that a novel zoonotic coronavirus had been the cause of this recent outbreak (Rothan and Byrareddy, 2020). By January 30'2020, the outbreak of this novel virus had been so rapid and far reaching, that World Health Organization (WHO) announced it as a Public Health Emergency of International Concern [PHEIC] (World Health Organization, 2020). On February 12'2020, WHO termed the disease triggered by this novel coronavirus, as Coronavirus Disease 2019 [COVID-19] (World Health Organization, 2020).

Since the outbreak of COVID-19 in December, the disease has spread on to affect many countries around the globe. By April 2,'2020, global confirmed positive cases reached 857,641, with 42,006 deaths, and 206 countries, areas or territories battling SARS-CoV-2. Although China was severely affected, as it was the center of outbreak of COVID-19, the outbreak is more concentrated now in North America, Europe and South East Asia. By April 02'2020, China reported 82,875 confirmed cases and 3,335 deaths. 82,872 COVID-19 positive cases, with 3,327 total deaths. While some other countries like United States of America [USA], 
Italy and Spain have surpassed China in terms of number of diseased people and deaths. According to WHO, United States of America was the most affected country, totaling 187,302 reported positive cases, and 3,846 deaths. While Italy was the second most affected country with cumulative 105,792 lab tested positive cases, and 12,430 deaths. Spain had ranked number third with 94,417 cases and 8,189 deaths. In South Asia, Islamic Republic of Iran was facing a major outbreak with total of 47593 cases, and 3,036 deaths (World Health Organization COVID-19 Dashboard, n.d.).

Pakistan is also fighting this novel corona virus COVID-19. A disease, for which there is currently no treatment nor vaccination available, it is a great challenge for a developing country already facing economic crisis, like Pakistan, to tackle a pandemic that has brought many developed countries to its knees. Hence, the purpose of this study is to collect, summarize, and analyze the day wise situation of Covid-19 in Pakistan, as well as measures taken by the government of Pakistan to prevent and control it. So, the aim of this study is to forecast trajectory of COVID-19 cases in Pakistan to bring the attention of the governing bodies to the alarming situation of COVID-19 growth in Pakistan. Through its summarized data, this study aims to provide assistance to national and international strategists to evaluate the current strategy against COVID19 in Pakistan and propose other if required. This study also aims to assist other researchers to compare the COVID-19 epidemiology in Pakistan with the world, and in future to conduct After Action Review (AAR) of the measures taken, and the best practices adopted against COVID-19.

\section{METHODOLOGY:}

This is a retrospective review study, in which official daily data of COVID 19 that was released by national agency NIH-Pakistan and international agency WHO, was collected. The data was collected on daily basis regarding COVID-19 suspected cases, number of lab tested cases with their outcome, and number of travelers screened form February 26'2020 to April 3'2020. Graph was used to show national statistics of compound growth rate of COVID-19 lab tested positive cases in Pakistan. Regional statistics were collected regarding cumulative data on suspected cases, tests performed, and tests with positive outcome. Percentages of regional cumulative tests positive, cumulative cases recovered and cumulative cases expired were also generated.

The forecasting of trajectory of COVID-19 in Pakistan was done by data analysis using SPSS version-23. Line chart was made, and forecasting was made using time series modeler / expert modeler. For each model, forecasts start after the last non-missing in the range of the requested estimation period, and end at the last period for which non-missing values of all the predictors are available or at the end date of the requested forecast period, whichever is earlier. The data was predicted for $4^{\text {th }}$ April till $30^{\text {th }}$ April.

\section{RESULTS: A. COVID-19 EPIDEMIOLOGY IN PAKISTAN:}

Pakistan reported its first case on February 26'2020. On March 10'2020, Pueyo (2020) an engineer, suggested a model to predict the rise in the COVID-19 cases based on either, total number of deaths or total number of positive cases. Based on that on March 16'2020, a journalist and an engineer Osama Rizvi and Ahsan Zahid (2020) suggested the trajectory of COVID-19 in Pakistan, if efficient and timely preventive measures are not in place. They stated on March 16'2020, that based on 94 true positive cases of COVID-19 in Pakistan, likely true cases in a month could be 79,419. Fortunately, by March 29'2020, around 15 days later, the total number of confirmed cases were, 1,526 with 29 recovered and 14 deaths. Critical cases treated in Intensive Care Unit were 11, which contributes to $0.7 \%$ of total cases. Daily cases receiving treatment were 1483, which amounts to $97.2 \%$ of total cases or, 7 confirmed cases per million population. Fatality Rate was $0.9 \%$ of the total cases, and Positive Rate was $1.9 \%$ of the total cases (Corona Tracker, n.d.). While on April 5'2020, total number of COVID-19 lab tested positive cases were 2,450, and 35 deaths (World Health Organization COVID-19 Dashboard, n.d.). However, on April 3'2020, the Prime Minister of Pakistan announced to reopen China-Pakistan Economic Corridor (CPEC) project and construction industry from April 4'2020, considering the rising economic pressures (The Nation, 2020). If Pueyo (2020) model of COVID-19 trajectory is applied on the increasing growth rate of COVID-19 in Pakistan, which is 23.5\% as of April 4, 2020, then Pakistan faces a great threat of blow up in the situation. With the industries reopening, how will curve of COVID-19 change, and what will be the strategy of Pakistan to tackle its COVID-19 and economy both, are the answers 
that need to be monitored in the future.

Daily situation report of COVID-19 in Pakistan, collected from the daily situation report published by National Institute of Health (n.d.), Pakistan is mentioned below in Table-1.

Table-1: Daily Situation Report of COVID-19 in Pakistan

Below is the graphical representation of growth rate of COVID-19, by calculating cumulative COVID-19 positive cases as of April 2'2020 in Pakistan. The data was collected from the official statistics shared by National Institute of Health (n.d.).

Figure-1: A graph of compound growth rate of COVID-19 positive cases in Pakistan

In Table-2, as of April 16'202, the regional statistics of COVID-19 in Pakistan, collected from Pak Wired (n.d.) are mentioned below.

Table 2: Regional statistics of COVID-19 in Pakistan

\section{B. FORECASTING:}

Our analysis of data and forecast from $4^{\text {th }}$ April till $30^{\text {th }}$ April is mentioned below in Table-3. Data is represented in Line chart and forecasted using time series modeler / expert modeler. Table 3: Forecasting of COVID-19 from $4^{\text {th }}$ April till $30^{\text {th }}$ April

NOTE: For each model, forecasts start after the last non-missing in the range of the requested estimation period, and end at the last period for which non-missing values of all the predictors are available or at the end date of the requested forecast period, whichever is earlier.

Figure 2: Forecasting of COVID-19 from $4^{\text {th }}$ April till $30^{\text {th }}$ April. According the figure, there may be around 8,000 cases of COVID-19 in Pakistan by the end of April'2020.

\section{MEASURES TAKEN BY GOVERNMENT OF PAKISTAN TO COMBAT COVID-19:}

COVID-19 pandemic has been a great challenge even for leading countries of the world like China, USA and Italy. For a developing country like Pakistan, that lacks a developed health care infrastructure as well as resources, along a current economic crisis, spread of COVID-19 is a threat beyond its means. Pakistan started to take preventive measures a month ago its first COVID-19 reported case. On March 14'2020. WHO representative visited Pakistan to evaluate the measures taken by the government of Pakistan. The steps to prevention of the federal and provincial governments were discussed, diagnostic lab, isolation facilities and health facilities were inspected. He declared the diagnostic labs and treatments facilities as "world class" but highlighted the need of increase in the testing facilities in public sector, if the cases increase.

With strict screening measures at the point of entry, 2,000 isolation beds, a mobile diagnostic facility dispatched at Taftan border to screen the pilgrims entering the country from Iran (an area of COVID-19 outbreak), seven diagnostic capable of diagnosing 15,000 patients, the response of Pakistan was declared "one the best national response programs among the world"(Qureshi, 2020). The preventive measures taken by the Government of Pakistan against COVID-19 are listed in a time line in the Table 4 below.

Table 4: Preventive measures taken by the Government of Pakistan against COVID-19

\section{DISCUSSION:}

An ongoing study by Roser, Ritchie and Ortiz-Ospina (2020) on Coronavirus Disease (COVID-19) - Statistics and Research, is currently sharing and comparing updated global data, from the database of European Center of Disease Control (CDC). Following is the comparison of COVID -19 situation among China, USA and Pakistan, during the time period of December 31'2019 to March 30'2020. China Reported its first COVID19 case in December'2020, while USA had its first confirm case on January 20'2020, and Pakistan had its first case almost a month after USA on February 26'2020, despite sharing a border, CPEC and extensive trade with China. As of April 15,'2020, China after experiencing its peak in the month of February'2020 
is now on decline. The cumulative statistics of China are 83,745 confirmed cases and 3,352 deaths. USA on the other hand is currently headed towards it peak, almost two month later after its first reported case. On April 15'2020, USA is the most affected country in the world with 578,268 confirmed cases and 23,476 deaths. Pakistan shows the least spread of COVID-19 among the three countries. Pakistan has had 5,988 confirmed cases and 107 deaths after almost 50 days of its first reported case, which is still far less than what was predicted by Rizvi and Zahid (2020) on March 16'2020 (World Health Organization COVID-19 Dashboard, n.d.).

But, is the situation still as safe as it has been? Will COVID-19 growth rate reduce or stay the same in Pakistan in future as well? Is the country prepared if the situation changes for worse? These are the questions we intend to bring to highlight in this article.

With in a week, with the compound growth rate of $17.3 \%$ of COVID-19, the per day cases of Pakistan has jumped from 250 to 520 on April 16'2020, while total number of lab tested positive cases has gone from 4072 to 7025. (Pak Wired, n.d.). The rate of COVID-19 growth as of today is rather faster and higher than we originally predicted in Table - 3 above, based on the data collected from February 26'2020 to April 3'2020. With recent rapid increase in growth of COVID-19, the cases by the end of April'2020 can go much higher than our initial prediction of 8,000 , which can pose a great threat and challenge for the governing bodies in Pakistan.

While, on April 14' 2020, the Prime Minister of Pakistan has also announced to open skilled labour industry along with CPEC and construction industry, which will loosen the lock down and the protective effect of social distancing against COVID-19. Succumbing to economic pressure the traders association in Karachi, has also announced to reopen the businesses in three out of four provinces, Sindh, southwestern Baluchistan, and northwestern Khyber Pakhtunkhwa (KP) on the same day (Anadolu Agency, 2020). Later in the day, the religious relics also announced to open the places of worship for five daily congregational prayers, as well as extra congregational prayers during the holy month of Ramadan while observing preventive protocols (Gulf News, 2020). With the current state of affairs of the country, and our COVID-19 forecast of 8,000 cases by the end of April'2020, the situation looks grave for the country. With loosened lock down and social distancing, while increasing growth rate of COVID-19 cases, there is a danger of an exponential growth in the COVID-19 cases in Pakistan.

WHO representative on March 14' 2020 declared the response of Pakistan as one of the best national responses. However, total foreign transmission of COVID-19 in Pakistan estimates about 46.6\%, which goes to show that Pakistan's border prevention strategy could have been improved and still needs to be revisited for future course. On the other hand, local transmission of COVID-19 accounts for $53.4 \%$ after a month of lock down in the country (Pak Wired, n.d.). The question that whether the reason of this relatively slower spread is only due to timely, efficient measures, or are there other factors involved, has yet to be answered. The role of other factors like, increased ratio of younger population, better immune status, warm climate (Accuweather, 2020) or under testing has been associated with slow spread COVID-19. Pakistan is a country of warm climate, and under reporting of COVID-19 is being brought to attention (The Express Tribune, 2020), however, contrary to many other countries COVID-19 in Pakistan is being reported more in the younger age group (Health Advisory Platform by Ministry of National Health Services Regulations and Coordination, 2020) Hence, it is important to further investigate the effect of these factors on epidemiological spread of COVID-19.

Hence, considering exponential growth of COVID -19 cases, along with recent economic decisions made to loosen the lock down, Pakistan seems to be at the verge of facing a COVID-19 outbreak challenge for which it does not appear to be prepared. So, through this study we aim to draw the attention of both national as well international governing bodies, administrators and researchers towards the re-evaluation and re-orientation of the current implemented COVID-19 prevention strategies, as well as preparedness of the country for a potential future health crisis.

\section{CONCLUSION:}


The government of Pakistan started taking preventive measures against COVID-19 before its outbreak in the country, and its response was considered satisfactory by WHO up until March 14'2020. But despite having preventive measures in place well before time, there has been a rapid increase in number of confirm positive cases of COVID-19 in Pakistan. The growth seems to go higher than what our study predicts, but slower than predicted by earlier researchers. However, Pakistan has opened CPEC, construction and skilled labour industry to relieve its economic burden, which in turn may worsen the COVID-19 situation in the country. Hence, the upcoming month is of considerable importance in epidemiological spread of COVID-19 in Pakistan. How will Pakistan manage both its COVID-19 cases and economy, is a situation to monitor. Also, a question that should be further investigated is the cause of less than expected spread of COVID-19 in Pakistan, compared to other active outbreak countries.

\section{ACKNOWLEDGMENT:}

We would like to acknowledge World Health Organization (WHO), National Institute of Health (NIH) Pakistan, and all the other open data sources from which we have collected the information.

\section{CONFLICT OF INTEREST:}

'Declarations of interest: none'. The authors declare that there is no conflict of interest regarding the publication of this paper.

\section{ETHICAL STATEMENT:}

The authors confirm that the ethical policies of the journal, as noted on the journal's author guidelines page, have been adhered to. No ethical approval was required as this is a review article with no original research data.

\section{DATA AVAILABILITY STATEMENT:}

The data that support the findings of this study are available in Global Health Observatory Data Repository at http://www.who.int/gho/database/en/, reference number 4, 17, 23, 33 40-42. These data were derived from the following resources available in the public domain:

- https://www.coronatracker.com/analytics/,

- https://www.searchnewworld.com/search/search2.html?partid=rolbng\&if $=G e o . t v .+2020 .+A+$ Timeline + Of + The + Sprec

- https://pakwired.com/the-pakistan-coronavirus-disease-tracker/

- http://covid.gov.pk/

- https://who.sprinklr.com,

\section{REFERENCES:}

1. Ayub, I. (2020, March 22). Centre to give Sindh govt $\$ 10 \mathrm{~m}$ from WB funds to fight coronavirus. Retrieved from https://www.dawn.com/news/1542702

2. Coronavirus disease 2019 (COVID-19). (n.d.). Retrieved from https://www.who.int/docs/defaultsource/coronaviruse/situation-reports/20200212-sitrep-23-ncov.pdf?sfvrsn=41e9fb78_4

3. COVID-19: Pakistan extends lockdown until April 30. (n.d.). Retrieved fromhttps://www.aa.com.tr/en/asiapacific/covid-19-pakistan-extends-lockdown-until-april-30/1804544

4. Corona Tracker. 2020. COVID-19 Related Analytics, Graphs, And Charts. [online] Available at: $<$ https://www.coronatracker.com/analytics/> [Accessed 7 April 2020].

5. Desk, W. (2020, March 11). A timeline of the spread of coronavirus in Pakistan. Retrieved from https://www.geo.tv/latest/276711-a-timeline-of-the-emergence-of-the-coronavirus-in-pakistan

6. Desk, W. (2020, March 9). Coronavirus: Pakistan extends border closure with Afghanistan for seven days. Retrieved from https://www.geo.tv/latest/276370-pakistan-extends-border-closure-withafghanistan-for-one-more-week

7. Desk, W. (2020, March 7). Coronavirus: After 14 days, Pakistan opens Taftan border with Iran for trade. Retrieved from https://www.thenews.com.pk/latest/625285-coronavirus-after-14-days-pakistanopens-taftan-border-with-iran-for-trade 
8. Desk, W. (2020, March 9). Coronavirus: Pakistan extends border closure with Afghanistan for seven days. Retrieved from https://www.geo.tv/latest/276370-pakistan-extends-border-closure-withafghanistan-for-one-more-week

9. Desk, W. (2020, March 13). Pakistan set to seal border with Afghanistan, Iran to prevent coronavirus spread. Retrieved from https://www.geo.tv/latest/277163-pakistan-set-to-seal-border-withafghanistan-iran-to-prevent-coronavirus-spread

10. Desk, W. (2020, March 12). Sindh govt extends closure of educational institutions till May 30 amid coronavirus fears. Retrieved from https://www.thenews.com.pk/latest/628126-govt-extends-educationalinstitutions-holidays-till-may-30-amid-coronavirus-fears

11. Desk, W. (2020, March 12). Medical emergency declared in Gilgit Baltistan to contain coronavirus. Retrieved from https://arynews.tv/en/medical-emergency-gilgit-baltistan-coronavirus-outbreak/

12. Desk, W. (2020, March 13). Pakistan set to seal border with Afghanistan, Iran to prevent coronavirus spread. Retrieved from https://www.geo.tv/latest/277163-pakistan-set-to-seal-border-withafghanistan-iran-to-prevent-coronavirus-spread

13. Desk, W. (2020, March 12). Sindh govt extends closure of educational institutions till May 30 amid coronavirus fears. Retrieved from https://www.thenews.com.pk/latest/628126-govt-extends-educationalinstitutions-holidays-till-may-30-amid-coronavirus-fears

14. Desk, W. (2020, March 12). Medical emergency declared in Gilgit Baltistan to contain coronavirus. Retrieved from https://arynews.tv/en/medical-emergency-gilgit-baltistan-coronavirus-outbreak/

15. Desk, W. (2020, March 23). Azad Jammu and Kashmir PM announces three-week lockdown. Retrieved from https://arynews.tv/en/azad-jammu-and-kashmir-pm-lockdown/

16. Desk, W. (2020, March 23). CM Punjab Usman Buzdar announces lockdown in Punjab. Retrieved from https://arynews.tv/en/cm-punjab-usman-buzdar-lockdown-punjab/

17. Geo.tv. 2020. A Timeline Of The Spread Of Coronavirus In Pakistan. [online] Available at: <https://www.geo.tv/latest a-timeline-of-the-emergence-of-the-coronavirus-in-pakistan> [Accessed 7 April 2020].

18. Govt Bans Marriage Halls, Tea Shops Functioning After 23:15 Hours. (n.d.). Retrieved from https://www.urdupoint.con bans-marriage-halls-tea-shops-functioni-860491.html

19. Haq, Z. U. (2020, March 13). Coronavirus: KP govt decides to close all educational institutions. Retrieved from https://arynews.tv/en/coronavirus-fears-kp-educational-institutions-closed/

20. Huang, C., Wang, Y., Li, X., Ren, L., Zhao, J., Hu, Y., Zhang, L., Fan, G., Xu, J., Gu, X. and Cheng, Z., 2020. Clinical features of patients infected with 2019 novel coronavirus in Wuhan, China. The Lancet, 395(10223), pp.497-506.

21. Jamal, S. (2020, January 29). Pakistan on high alert amid coronavirus outbreak in China. Retrieved from https://gulfnews.com/world/asia/pakistan/pakistan-on-high-alert-amid-coronavirus-outbreak-inchina-1.69234333

22. Junaidi, I., \& Nagri, J. (2020, January 27). Coronavirus fear: GB seeks delay in opening of border crossing. Retrieved from https://www.dawn.com/news/1530743

23. Khalid, Z., 2020. The Pakistan Coronavirus (COVID-19) Disease Tracker. [online] PakWired - Latest Startup and Technology News from Pakistan. Available at: < https://pakwired.com/the-pakistancoronavirus-disease-tracker/> [Accessed 7 April 2020].

24. Li, Q., Guan, X., Wu, P., Wang, X., Zhou, L., Tong, Y., Ren, R., Leung, K.S., Lau, E.H., Wong, J.Y. and Xing, X., 2020. Early transmission dynamics in Wuhan, China, of novel coronavirus-infected pneumonia. New England Journal of Medicine.

25. Medium. 2020. Coronavirus: Why You Must Act Now. [online] Available at: <https://medium.com/@tomaspueyo/cor act-today-or-people-will-die-f4d3d9cd99ca> [Accessed 7 April 2020].

26. Naya Daur. 2020. Coronavirus In Pakistan: Data Shows Number Will Rise To 80,000 By Mid-April. [online] Available at:

27. Number of coronavirus cases in Pakistan jumps to 28: officials: SAMAA. (n.d.). Retrieved from https://www.samaa.tv/living/health/2020/03/number-of-coronavirus-cases-in-pakistan-jumps-to-28-officials/

28. Pakistan Shuts Borders Amid Coronavirus Outbreak. (2020, March 16). Retrieved from https://skift.com/2020/03/13/1 shuts-borders-amid-coronavirus-outbreak/ 
29. Pakistan Shuts Borders Amid Coronavirus Outbreak. (2020, March 16). Retrieved from https://skift.com/2020/03/13/1 shuts-borders-amid-coronavirus-outbreak/

30. Reuters. (2020, March 21). Pakistan suspends international flights for two weeks. Retrieved from https://www.theguardian.com/world/2020/mar/21/pakistan-suspends-international-flights-for-two-weeksto-stem-covid-19-spread

31. Reuters. (2020, April 15). COVID-19: Pakistan clerics call for lifting of congregational prayer limits. Retrieved from https://gulfnews.com/world/asia/pakistan/covid-19-pakistan-clerics-call-for-lifting-ofcongregational-prayer-limits-1.70988562

32. Rothan, H.A. and Byrareddy, S.N., 2020. The epidemiology and pathogenesis of coronavirus disease (COVID-19) outbreak. Journal of autoimmunity, p.102433

33. See the Realtime Pakistan and Worldwide COVID-19 situation! (n.d.). Retrieved from http://covid.gov.pk/

34. The Nation. 2020. NCC Decides To Open Work On CPEC Projects. [online] Available at: <https://nation.com.pk/03Apr-2020/ncc-decides-to-open-work-on-cpec-projects> [Accessed 7 April 2020].

35. Tribune.com.pk. (2020, March 22). Sindh decides to go into COVID-19 lock down. Retrieved from https://tribune.com.pk/story/2181138/1-sindh-govt-mulls-total-lockdown-provincial-covid-19-tally-crosses$350 /$

36. Wintour, P. (2020, February 23). Turkey and Pakistan close borders with Iran over coronavirus deaths. Retrieved from https://www.theguardian.com/world/2020/feb/23/turkey-and-pakistan-close-borderswith-iran-over-coronavirus-deaths

37. World Health Organization. (2020). WHO Director-General's remarks at the media briefing on 2019nCoV on 11 February 2020. 2020-02-11)[2020-02-24]. https://www. who. int/dg/speeches/detail/whodirector-general-s-remarks-at-the-mediabriefing-on-2019-ncov-on-11-february-2020.

38. World Health Organization. (2005). Statement on the second meeting of the International Health Regulations (2005) Emergency Committee regarding the outbreak of novel coronavirus (2019-nCoV).

39. Who.int. 2020. [online] Available at: <https://www.who.int/docs/default-source/coronaviruse/situationreports/20200310-sitrep-50-covid-19.pdf?sfvrsn=55e904fb_2> [Accessed 7 April 2020].

40. Who.sprinklr.com. 2020. WHO COVID-19 Dashboard. [online] Available at: <https://who.sprinklr.com/> [Accessed 02 April 2020].

41. Who.sprinklr.com. 2020. WHO COVID-19 Dashboard. [online] Available at: <https://who.sprinklr.com/> [Accessed 05 April 2020].

42. Who.sprinklr.com. 2020. WHO COVID-19 Dashboard. [online] Available at: <https://who.sprinklr.com/> [Accessed 15 April 2020].

43. Zubair Qureshi, C., 2020. Pakistan'S Response To Coronavirus Among World'S Best, Says WHO Country Head. [online] Gulfnews.com. Available at: <https://gulfnews.com/world/asia/pakistan/pakistansresponse-to-coronavirus-among-worlds-best-says-who-country-head-1.70388431> [Accessed 7 April 2020].

\section{Hosted file}

Tables of the mauscript.docx available at https://authorea.com/users/312682/articles/443245covid-19-forecast-of-an-emerging-urgency-in-pakistan

\section{Hosted file}

Figures of the review .docx available at https://authorea.com/users/312682/articles/443245-covid19-forecast-of-an-emerging-urgency-in-pakistan 